\title{
Vloga akcijskega raziskovanja pri medpredmetnem povezovanju
}

\author{
Tina Štemberger \\ Univerza na Primorskem \\ tina.stemberger@pef.upr.si
}

\begin{abstract}
Prispevek izhaja iz teze, da je medpredmetno povezovanje ena izmed ključnih usmeritev razvoja izobraževanja, ki jo je potrebno načrtovati in implementirati načrtno ter sistematično. Vpeljevanje takšnega načina dela zahteva tudi natančno spremljanje in ugotavljanje morebitnih učinkov, torej evalvacije in refleksije opravljenega dela. Spremembe je smiselno uvajati v manjših korakih in ciklično, pri čemer se $v$ celotnem procesu medpredmetnega povezovanja predpostavlja tudi sodelovanje učiteljev, torej timsko delo. Vsi ti elementi sovpadajo z značilnostmi akcijskega raziskovanja, ki ga zato tudi predstavljamo v prispevku. Prispevek zaključimo s poizkusom prikaza implementacije medpredmetnega povezovanja skozi akcijsko raziskavo. Osredotočamo se na tiste značilnosti akcijske raziskave, zaradi katerih menimo, da je akcijsko raziskovanje eden od ustreznih načinov vpeljevanja medpredmetnega povezovanja, ki izhaja iz potreb vzgojno-izobraževalne prakse, torej potreb učencev in učiteljev in ne iz nareka zunanjih institucij.
\end{abstract}

Ključne besede: medpredmetno povezovanje, akcijska raziskava, sodelovanje, refleksija, šolski razvojni tim

\section{Uvod}

Medpredmetno povezovanje velja za enega od ključnih konceptov usmeritev razvoja izobraževanja (Ivanuš Grmek 2009). Kljub temu pa, kot ugotavlja M. Volk (2019), v slovenskem šolskem polju, v nasprotju z mednarodnim prostorom, ni prav veliko dostopne strokovne literature o tej tematiki. Avtorji Bele knjige (Krek in Metljak 2011) se medpredmetnega povezovanja dotaknejo $v$ točki, ko priporočajo združevanje predmetov, s čimer bi zmanjšali njihovo število. Na ta način se učence razbremeni vsakodnevne priprave na več predmetov ter poveča možnosti za povezovanje znanja in medpredmetno povezovanje. Med vidnejše poizkuse sistematične vpeljave medpredmetnega povezovanja lahko uvrstimo model medpredmetnega in kurikularnega povezovanja na stopnji gimnazijskega izobraževanja (Rutar Ilc 2010). V tem modelu so bile postavljene smernice, kako naj šola pristopi k načrtovanju in izvajanju medpredmetnih povezav, kako naj se skupine učiteljev organizirajo in izvedejo medpredmetne povezave ter kako naj se takšen pouk načrtuje in 
ocenjuje njegove dosežke. Opravljena je bila tudi evalvacijska študija »Medpredmetno povezovanje vzgojno-izobraževalnega procesa v 9-letni osnovni šoli« (Sardoč idr. 2004), ki se je usmerila v ocenjevanje obsega in kakovosti ter pogojev medpredmetnega povezovanja vsebin, tako na ravni kurikularnega načrtovanja kot na ravni implementacije kurikula, in v identifikacijo načinov in mest, s katerimi bi integracijo izobraževalnih vsebin v zadnjem triletju devetletne osnovne šole lahko še izboljšali. Ugotovljeno je bilo, da so na ravni kurikularnega načrtovanja medpredmetne povezave prisotne $v$ veliki večini učnih načrtov.

Vendar prisotnost načrtovanja medpredmetnih povezav $v$ učnih načrtih ne zadostuje, saj načeloma še ne zagotavlja dejanskega medpredmetnega povezovanja. Ta način poučevanja (Volk 2019) od učitelja ne zahteva le sprememb pri ustaljenem načinu poučevanja, ampak tudi več sodelovanja s sodelavci pri oblikovanju skupnih učnih ciljev, razvijanju in usklajevanju učnih dosežkov ter uporabi ustreznih metod preverjanja in ocenjevanja. $V$ tem procesu ne smejo in ne morejo izostati elementi, ki so pomembni za učinkovito sodelovanje, kot so, denimo, medsebojna podpora učiteljev pa tudi zaupanje ter občutek varnosti, ki so predpogoj za skupno razvijanje znanja oz. preizkušanje različnih metod poučevanja in učenja (Lake 1994). Hkrati se pri medpredmetnem poučevanju pokažejo tudi podobnosti in razlike med učitelji, ki sodelujejo pri povezovanju predmetov, zato takšno poučevanje zahteva več časa in usklajevanja za načrtovanje in izvedbo učnih ur (Polak 2007). Za uspešno in učinkovito povezovanje predmetov je ključnega pomena sodelovanje učiteljev oz. timsko delo, ki na učence deluje stimulativno, ohranja višjo raven pozornosti, omogoča celostnejši pogled na obravnavano vsebino in pomeni neposreden zgled sodelovanja ter sodelovalnega učenja (Polak 2007). Ker so za uresničevanje medpredmetnega povezovanja ključni ustrezno usposobljeni in motivirani učitelji, je potrebno upoštevati tudi njihove poglede in predloge.

Učitelji so tako poročali (Sardoč idr. 2004), da bi bilo za doseganje primerne ravni vključevanja medpredmetnih povezav, tako na ravni načrtovanja kot na ravni izvedbe, potrebno uvesti izboljšave na področjih:

- sodelovanja med učitelji,

- formalnega izobraževanja učiteljev,

- dodatnega strokovnega izpopolnjevanja učiteljev,

- sodelovanja s strokovnjaki različnih predmetnih področij,

- dostopnosti gradiv in učnih pripomočkov,

- kakovosti didaktičnih gradiv in učnih pripomočkov. 
Ob tem pa se kaže tudi, da medpredmetno povezovanje od učiteljev zahteva predvsem večje sodelovanje med njimi v fazi načrtovanja ter $v$ fazi implementacije (Sardoč idr. 2004). Rezultati študije kažejo tudi, da učitelji ocenjujejo, da v okviru formalnega izobraževanja za poklic niso pridobili zadostnega znanja za izvajanje medpredmetnega povezovanja.

Zaradi dejstva, da učitelji izražajo potrebe po večjem sodelovanju, dodatnem strokovnem izpopolnjevanju in sodelovanju s strokovnjaki $z$ različnih predmetnih področjih, ocenjujemo, da bi lahko tako načrtovanje kot implementacijo in razvoj medpredmetnega povezovanja na šoli, tudi, denimo, $v$ okviru razvojnih timov, realizirali skozi akcijsko raziskovanje. Akcijsko raziskovanje se prav zaradi sodelovalne narave ter usmerjenosti v izboljševanje vzgojno-izobraževalne prakse zdi smiselna oblika vpeljave in razvoja medpredmetnega sodelovanja. $V$ prispevku bomo zato najprej na kratko predstavili ključne značilnosti ter faze in vrste tovrstnega raziskovanja. Usmerimo se tudi v vprašanje vrednotenja akcijskega raziskovanja in nekatere izzive, ki so povezani z akcijskim raziskovanjem, ter zaključimo s poskusom opredelitve vloge akcijskega raziskovanja v medpredmetnem povezovanju.

\section{Kaj je akcijsko raziskovanje?}

Lewin (1948 v Stringer 2008) akcijsko raziskovanje definira kot cikličen, dinamičen in sodelovalen proces, raziskavo pa kot niz korakov v spirali. Pri tem vsak korak zajema načrtovanje, akcijo in oceno doseženega rezultata. $V$ procesu raziskovanja se raziskovalci ukvarjajo $z$ družbenimi vprašanji, ki vplivajo na njihovo življenje. Kemmis in McTaggart (1988) sta Lewinovo opredelitev razširila na raven kolektivnega raziskovanja, saj menita, da je akcijsko raziskovanje oblika kolektivnega, razmišljujočega raziskovanja, ki ga izvajajo udeleženci $v$ določenih družbenih in izobraževalnih kontekstih, ter hkrati lastno razumevanje teh kontekstov in spletov okoliščin, $v$ katerih se navade uresničujejo (v Stringer 2008). Carr in Kemmis (1986) utemeljujeta, da akcijsko raziskovanje razvija dialektični pogled na racionalnost kot socialno konstrukcijo in ob tem sistematično razvija učiteljeve interpretacije kategorije. Na področju izobraževanja se kot enega ključnih začetnikov akcijskega raziskovanja omenja Coreya (1953 v Stringer 2008), ki je izhajal iz prepričanja, da je za spremembe oz. izboljšave vzgojno-izobraževalne prakse učitelja pomembna njegova osebna vključenost v raziskovanje lastne prakse. Bassey (1998) akcijsko raziskovanje na področju izobraževanja opredeljuje kot obliko raziskovanja, ki jo izvajajo učitelji z namenom spoznavanja, preučevanja in evalvacije svojega dela, v katerega posledično vnesejo spremembe, ki naj bi služile izboljšanju vzgojno-izobraževalne prakse. Izpostaviti velja tudi, da cilj akcijskega raz- 
iskovanja ni toliko v pridobivanju nekih splošnih spoznanj, kot je v spodbujanju profesionalnega razvoja učiteljev (Borg 1965). Kot povzemajo Vogrinc, M. Valenčič Zuljan in Krek (2007), akcijsko raziskovanje izvajajo praktiki, ki poskušajo poiskati rešitve za vsakodnevna vprašanja vzgojno-izobraževalne prakse. $V$ procesu raziskovanja učitelji pridobivajo novo znanje in se profesionalno razvijajo. M. Velikonja (2000) akcijsko raziskovanje razume kot eno od strategij, kako spreminjati izobraževalno prakso. Gre namreč za obliko razmišljajočega preučevanja, ki se ga lotevajo učitelji, da bi izboljšali svoje praktično ravnanje, razumevanje prakse in objektivnih možnosti, v katerem le-to poteka. Cohen, Manion in Morrison (2007) navajajo nekaj primerov, v katerih je akcijsko raziskovanje lahko zelo učinkovito, npr.: metode poučevanja (nadomeščanje običajnih metod $z$ inovativnimi), strategije učenja (uporaba integriranega pristopa v primerjavi s predmetnospecifičnim), evalvacija, profesionalni razvoj učiteljev pa tudi področje upravljanja in administracije (npr. višja učinkovitost).

Mills (2011) povzema razloge, ki upravičujejo uporabo akcijskega raziskovanja v šolah:

- akcijsko raziskovanje spodbuja spremembe $v$ šolah;

- spodbuja participacijo različnih deležnikov (npr. učiteljev, učencev, vodstva ipd.);

- učitelji pridobivajo kompetence skozi sodelovanje v projektih;

- spodbuja učitelje, da reflektirajo svojo prakso;

- spodbuja preizkušanje novih idej.

Kot zaključujejo Cohen, Manion in Morrison (2007), se akcijsko raziskovanje lahko uporabi v praktično vsaki situaciji, kjer se pojavi neka težava, ki vključuje ljudi, naloge in postopke, ali kjer se pojavi želja po izboljšavi situacije. Za področje vzgoje in izobraževanje velja, da lahko pobudo za akcijsko raziskavo da posamezen učitelj ali skupina učiteljev v neki šoli ali učitelj(i) skupaj z raziskovalcem.

\section{Značilnosti in faze akcijskega raziskovanja}

O značilnostih akcijskega raziskovanja so pisali številni avtorji, mi pa povzemamo nekatere ključne značilnosti: sodelovanje učiteljev in raziskovalcev, usmerjenost $v$ vprašanja neposredne vzgojno-izobraževalne prakse, cikličnost in dinamičnost raziskovalnega procesa.

Sodelovanje med raziskovalci in učitelji temelji na partnerskem odnosu, v katerem so praktiki soustvarjalci in soizvajalci (Sagadin 1989). Pri akcijski ra- 


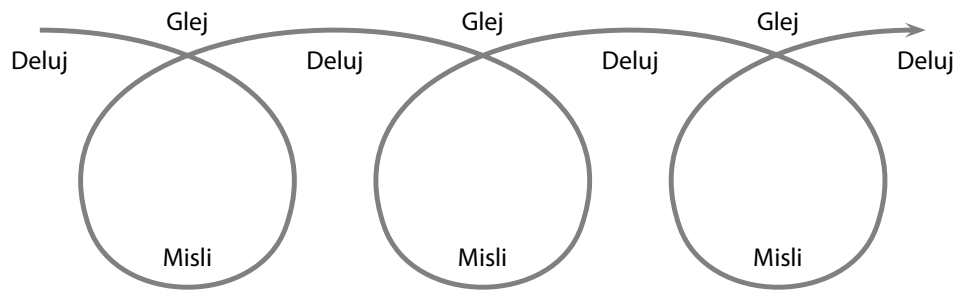

Slika 1 Vijačnica akcijskega raziskovanja (povzeto po Stringer 2008, 19)

ziskavi pa sodelujeta ne le raziskovalec in učitelj, pač pa gre tudi za sodelovanje $v$ širšem pomenu, saj se $v$ raziskavo, glede na cilje, lahko vključijo tudi učenci, svetovalni in drugi strokovni delavci, vodja ipd. (Creswell 2012).

Gre za navezovanje novih vidikov in rešitev za probleme pedagoške prakse, pri čemer je akcijsko raziskovanje vključeno neposredno $v$ sam inovacijski proces - v snovanje novosti, njihovo izvajanje, preizkušanje, vrednotenje in izpopolnjevanje (Sagadin 1989). Usmerjeno je torej v izboljševanje lastne vzgojno-izobraževalne prakse, saj je učitelj aktivni raziskovalec svojega dela (Creswell 2012), ali kot sta zapisala Carr in Kemmis (1986), akcijsko raziskovanje izvajajo tisti, ki jih določena situacija neposredno zadeva, ki torej v njej živijo ali delujejo, pri čemer je za izbor raziskovalnega problema pomembna tudi osebna vključenost.

Pomembna značilnost akcijskega raziskovanja je tudi njegova cikličnost (Stringer 2008; Vogrinc, Valenčič Zuljan in Krek 2007; Mažgon 2008; Kemmis idr. 1991; Cohen, Manion in Morrison 2007). Poteka namreč kot niz korakov, pri katerih vsak sestoji iz načrtovanja akcije in ocene doseženega rezultata (Lewin 1948 v Stringer 2008).

Hkrati je proces tudi zelo dinamičen (Creswell 2012), ne sledi linearnemu vzorcu sekvenc in poteka v skladu s cilji in okoliščinami institucije, v kateri poteka, okoliščine pa skuša tudi izpopolniti oziroma spreminjati (Carr in Kemmis 1986).

Povzeli bi lahko (Stringer 2008; Kemmis idr. 1991), da se akcijsko raziskovanje začne $s$ spoznanjem, da je $v$ vzgojno-izobraževalnem procesu potrebna neka sprememba ali izboljšava. Nato je potreben razmislek o možnostih vplivanja, torej, potrebno je preučiti dejavnike in razmere, ki lahko vplivajo na akcijo. Še pred samo izvedbo akcije (torej določenega ukrepa) moramo tudi predvideti način, kako bomo spremljali oz. beležili učinke. Z izvajanjem akcije pridobimo nove podatke, ki jih evalviramo, kar nas nato privede do naslednjega koraka, ki izhaja iz prvega. Proces se $v$ drugem ciklu $v$ tem zaporedju ponovi. Pomembno je izpostaviti, da je načrtovanje akcije vselej prožno, saj 


\section{Slika 2}

Ciklični potek akcijskega raziskovanja (povzeto po Kemmis idr. 1991, 53)

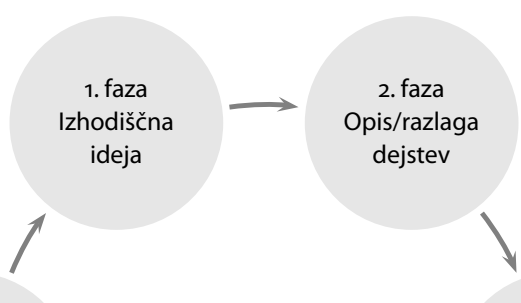

6. faza

Razlaga

učinkov

v kompleksnih socialnih situacijah ni možno predvideti prav vsega, kar bo potrebno storiti. Poleg vijačnice se akcijsko raziskovanje lahko nekoliko natančneje ponazori s cikličnim oz. spiralnim potekom (glej sliko 2) (Elliott 1981 v Kemmis idr. 1991).

Kemmis in McTaggart (1988) sta opredelila štiri ključne faze akcijskega raziskovanja:

- izdelava načrta za akcijo, ki naj bi vodila v izboljšanje oz. spreminjanje;

- ukrepi za uresničitev načrta;

- opazovanje in spremljanje učinkov teh ukrepov v okvirih, znotraj katerih potekajo;

- premislek o učinkih (refleksija), ki je podlaga za nadaljnje načrtovanje.

Te »osnovne« faze so raziskovalci dopolnjevali oz. izpopolnjevali ter jih nekoliko natančneje opisali (Kemmis idr. 1991, 53).

$\checkmark$ spiralnem poteku akcijskega raziskovanja so predstavljene faze poteka akcijske raziskave, ki jih v nadaljevanju nekoliko podrobneje opisujemo.

\section{Prva faza: izhodiščna ideja oz. oblikovanje problema}

$\mathrm{Na}$ začetku, torej še preden se akcijskega raziskovanja lotimo, se oblikuje neka izhodiščna ideja o ciljih, ki naj bi jih s to raziskavo dosegli. Običajno gre za splošnejšo idejo o ciljih in poteh. Cilji so lahko raziskovalni in praktični. Raz- 
iskovalni so v oblikovanju, razvijanju in preizkušanju inovacije, praktični pa v hkratnem spreminjanju, inoviranju pedagoške prakse ter vzporednem usposabljanju in motiviranju učiteljev za spremenjen način dela (Sagadin 1989). Oblikovanje izhodiščne ideje naj bi potekalo v manjših skupinah (5-10 članov), kar omogoča, da vsak od članov poda svoje ideje in predloge (Kemmis idr. 1991).

\section{Druga faza: opis/razlaga dejstev}

V tej fazi je potrebno izhodiščno idejo preučiti v kontekstu vzgojno-izobraževalne situacije (ali akcijskega polja), v kateri bo potekalo akcijsko raziskovanje, kar vključuje tudi pregled relevantne tako znanstvene kot strokovne literature, ki omogoča oblikovanje teoretične podlage. Pomemben element te faze je tudi prispevek učiteljev, torej njihovi pogledi in poznavanje situacije (Sagadin 1989), s čimer pripomorejo k čim popolnejšemu opisu stanja in okoliščin (Kemmis idr. 1991).

\section{Tretja faza: načrtovanje akcije}

Na podlagi zastavljenih ciljev ter opisa/razlage dejstev se je potrebno odločiti o tem, kako se bo cilj skušalo doseči. Analizirati in presojati je potrebno različne možnosti, prednosti in pomanjkljivosti za prakso in teorijo. Pri akcijskih raziskavah velja, da je ta odločitev lahko bolj ali manj podrobna, bolj ali manj operativna ter bolj ali manj dokončna. $V$ nekaterih primerih gre lahko za zelo podrobne členitve in navedbe raziskovalnih hipotez, $v$ drugih pa se ostaja le pri grobi formulaciji slednjih. Vendarle pa naj bi vsaj idejni načrt za celotno raziskavo, tudi akcijski koraki ter operativni načrt za prvi akcijski načrt, nastal že v času začetnega načrtovanja (Sagadin 1989). Kot navajajo Kemmis idr. (1991), raziskovalci v tej fazi skušajo poiskati odgovore na vprašanja: kaj bomo spreminjali, da bi stanje izboljšali, kakšne ukrepe bo potrebno sprejeti in s kom se bo potrebno pogajati oz. dogovarjati, kateri pripomočki, oprema, prostori so potrebni, koliko časa bomo potrebovali, kako se bo spremljajo učinke in, $s$ tem $v$ povezavi, katere tehnike zbiranja in obdelave podatkov bomo uporabili. Upoštevati pa je potrebno tudi etični vidik česa, npr. prostovoljnost, zaupnost, seznanjenost udeležencev ipd. Elliott (1981 v Kemmis idr. 1991) zapiše, da si v akcijski raziskavi raziskovalci zastavljajo tri vrste praktičnih raziskovalnih vprašanj, in sicer:

- vprašanja, ki identificirajo oz. opredeljujejo (npr. orientacija na lastna čustva: kdaj v razredu doživljam negativna čustva, orientacija na učne postopke: ko uvajam skupinsko delo, ali je to res osmišljeno v neki dani 
situaciji, orientacija na občutja: v katerih situacijah učenci doživljajo stres ipd.);

- vprašanja, ki razjasnjujejo (diagnosticirajo) praktične probleme in se usmerjajo v kavzalne-vzročne faktorje (npr. zakaj občutim napetost, zakaj jim skupinsko delo ne ustreza ipd.);

- vprašanja, ki pomagajo pri reševanju doživetih problemov in se osredinjajo na nove, drugačne pristope, strategije.

\section{Četrta faza: uvajanje akcije (1. akcijski korak)}

Po pripravi načrta se izvede prvi akcijski korak; njegova izvedba se spremlja in evalvira (Sagadin 1989). Prvi akcijski korak je potrebno izdelati zelo podrobno, in sicer mora vključevati (Velikonja 2000):

- natančen opis, kaj se bo v praksi spreminjalo;

- utemeljitev načrtovane strateške akcije: zapišejo se razlogi za akcijo in predvidevanja, kako bo ta vplivala na udeležence, učenje, organizacijo itn.;

- zapis predvidenih učinkov, tako negativnih kot pozitivnih, ter odziv na negativne učinke;

- identifikacija oseb, ki jih akcija vključuje ali neposredno zadeva, ter zapis, kako so te osebe vključene $v$ akcijo ter kakšna je njihova vloga $v$ prvem akcijskem koraku;

- zagotavljanje sredstev (prostori, gradivo, oprema ipd.);

- predvidenje morebitnih ovir in težav.

\section{Peta in šesta faza: spremljanje in razlaga učinkov}

$Z$ namenom spremljanja in razlage učinkov je v procesu izvajanja akcije potrebno zbirati podatke, kar se, skladno $z$ namenom raziskave, opredeli že $v$ sami fazi načrtovanja raziskave.

Akcijo je potrebno spremljati z vseh zornih kotov (raziskovalci, učenci, kolegi, ravnatelji in morebitni drugi vpeti v raziskavo). Spremljanje se nanaša tako na vprašanja, ki zadevajo strateško akcijo kot proces, kot tudi na posledice strateške akcije in okoliščine, $v$ katerih je potekala (Velikonja 2000). Tehnike zbiranja podatkov so raznolike, pretežno (ne ekskluzivno) pa so kvalitativne. $V$ praksi se uporabljajo predvsem naslednje.

- Intervjuji z udeleženci, ki naj bi potekali v prijetnem okolju in omogočali preprosto izmenjavo informacij. Intervju je časovno običajno zelo zahteven, a gre za plodne pogovore, ki udeležencem raziskave omogo- 
čajo delno poglabljanje v problem in sočasno razvijanje razumevanja, zaupanja in dobrih delovnih odnosov (Stringer 2008, 77-79).

- Skupinske diskusije (ali fokusne skupine), ki udeležencem omogočajo, da si izmenjujejo informacije in s tem sprožajo nove zamisli ali poglede (str. 89).

- Opazovanje, zlasti nestrukturirano, s ciljem pridobiti podrobnejše opise dejanj ljudi in okoliščin, v katerih se pojavljajo. Vendarle pa mora biti opazovanje osredotočeno, da se zapisujejo le podrobnosti, ki so povezane $z$ akcijo (str. 94).

- Fotografije in videoposnetki, ki se jih posname med akcijo in se lahko kasneje uporabljajo tudi kot sredstvo za spodbujanje razprave med skupinskimi diskusijami (str. 95-96).

- Dokumenti, ki so na razpolago, npr. učne priprave, učni načrti, urnik, predpisi, pravilniki, različna poročila ipd. (str. 97).

- Pisanje raziskovalnega dnevnika, ki ga imajo nekateri (Altrichter in Posch 1990 v Kemmis idr. 1991, 61-62) za osnovno raziskovalno orodje v akcijskem raziskovanju. Oblika in sestavine niso predpisane, pomembno pa je, da ga učitelj piše razmeroma redno, da piše najprej zase in da vedno avtor sam določa, katere dele bo dal v branje drugim in katerih ne. Dnevnik naj bi vseboval tudi občutja, razmišljanja, slutnje, razlage pa tudi pomembnejše dokumente, fotografije ipd.

Akcijsko raziskovanje pa ne izključuje tudi kvantitativnejših tehnik zbiranja podatkov, torej različnih anketnih vprašanj, lestvic stališč, ocenjevalnih lestvic, »ček list« pa tudi sociograma (Kemmis idr 2008).

Pri zbiranju podatkov v akcijskem raziskovanju se večkrat uporablja triangulacijo, tj. kombinira se podatke, ki so bili pridobljeni na različne načine, npr. podatke intervjujev, opazovanj. Tak način omogoča, da se podatke iz iste situacije osvetli z različnih perspektiv, npr. perspektive učitelja, učenca, opazovalca (Marentič Požarnik 1987, 46-47).

\section{Sedma faza: evalvacija in refleksija}

Evalvacija je namenjena ugotavljanju, vrednotenju in razlagi rezultatov (učinkov, dosežkov), ki se navezujejo na odlike, pomanjkljivosti akcijskega koraka, načrta in procesa izvedbe. Lahko je formativna (oblikovalna, sprotna) ali sumativna (končna, sklepna). Formativna omogoča sprotno presojo akcije in pravočasne posege vanjo za izboljševanje, sumativna pa pripomore pri končni presoji izvedenega koraka ter pri odločitvah o nadaljnjih postopkov oz. akcijskih korakih. Za evalvacijo je značilno tesno sodelovanje učiteljev 
in raziskovalcev, ki se na ta način učijo in pridobijo nov vpogled v vzgojnoizobraževalno prakso (Sagadin 1989).

Za akcijsko raziskavo je pomembna tudi refleksija, ki skuša osmisliti procese, problem vprašanja in omejevalne dejavnike. Refleksija (Schon 1983) je namreč delovanje strokovnih delavcev, ki razmišljajo o svojem ravnanju, ga analizirajo, delujejo premišljeno in ne sprejemajo prenagljenih odločitev. V tem procesu se učitelj sooči z lastnimi subjektivnimi teorijami in izkušnjami ter jih kritično preveri. Tako $v$ akcijskem raziskovanju (Kemmis idr. 1991) učitelji izkušnjo akcije pretehtajo in presodijo, ali so bili rezultati zaželeni in ali odpirajo možnost za nadaljnje delo. Običajno poteka v obliki debate, ki pripomore, da refleksija privede do rekonstrukcije pomena socialne situacije in zagotovi temelj za poglobljen pregled načrta.

\section{Osma oz. prva faza: izhodiščna ideja (problem)}

Po zaključeni sedmi fazi, torej po evalvaciji in refleksiji, se raziskava lahko nadaljuje z novim akcijskim krogom (ki ponovno vključuje vse faze), pri čemer prva faza, torej izhodiščna ideja, temelji na evalvaciji in refleksiji predhodnega akcijskega kroga. Običajno sta za akcijsko raziskavo potrebna vsaj dva akcijska kroga.

\section{Vrste akcijskega raziskovanja in vrednotenje akcijske raziskave}

Mills (2011) povzema, da lahko znotraj akcijskega raziskovanja govorimo o t. i. akcijski raziskavi za praktične namene ter o participativni akcijski raziskavi.

Akcijska raziskava za praktične namene se usmerja v raziskovanje vzgojnoizobraževalnih situacij v razredu pa tudi šoli. Končni cilj je običajno izboljšanje učnih dosežkov učencev ali strokovna rast učiteljev. Time, ki izvajajo akcijsko raziskavo, sestavljajo učitelji, učenci, svetovalci pa tudi administrativni delavci. Akcijske raziskave za praktične namene so običajno neke manjše raziskave, ki se pretežno ozko usmerjajo $v$ točno določen problem. Participativna akcijska raziskava pa je usmerjena $v$ skupnost in poudarja pomen prispevka za spremembe $v$ družbi. Končni cilj je izboljšanje organizacij, skupnosti in družinskega življenja (glej tudi Stringer 2008), preko opolnomočenja tako posameznikov kot večjih skupin (npr. vzgojno-izobraževalnih zavodov).

Akcijske raziskave se presoja tudi z vidika kakovosti izvedbe in učinka. Običajno se za vrednotenje uporabljajo naslednji kriteriji (Carr in Kemmis 1986; Mills 2011) presojanja kakovosti posamezne akcijske raziskave:

- ali se akcijska raziskava osredotoča na problem iz prakse ali na nek element, ki je pomemben v skupnosti; 
- ali so uporabljene različne, tako kvalitativne kot kvantitativne, tehnike zbiranja podatkov, ki se izberejo na osnovi raziskovalnega problema;

- kako je organizirano in kako poteka sodelovanje z drugimi z namenom iskanja optimalnih rešitev;

- ali imajo vsi partnerji v raziskavi enakovreden položaj, kakšno je medsebojno spoštovanje;

- ali je pripravljen načrt za rešitev problema;

- ali je bila opravljena refleksija lastnega profesionalnega razvoja;

- ali je razvit načrt predlaganih sprememb v praksi;

- ali je poročilo o raziskavi razumljivo vsem ključnim deležnikom.

Tudi pri akcijski raziskavi je potrebno upoštevati etični vidik raziskovanja, zlasti v povezavi s pomembno vlogo vključenih v raziskavo. Vodja akcijske raziskave mora raziskavo voditi na način, ki omogoča skrb za udeležence, skrbeti mora za sodelovalno raziskovanje $v$ vseh fazah raziskave. Pri tovrstni raziskavi so neredko določeni deli neznani, zato je potrebno vedno znova preverjati strinjanje s sodelovanjem $v$ raziskavi in udeležencem dopuščati, da iz raziskave izstopijo (Creswell 2012).

\section{Namesto zaključka: na kakšen način lahko akcijsko raziskovanje spodbuja medpredmetno povezovanje?}

Vrnimo se na začetek prispevka in k temeljnemu dokumentu na področju vzgoje in izobraževanja - Beli knjigi (Krek in Metljak 2011). V tej je zapisano, da se priporoča združevanje predmetov, kar bi posledično zmanjšalo število predmetov, učence razbremenilo vsakodnevne priprave na več predmetov in povečalo možnosti za povezovanje znanja ter medpredmetno povezovanje. Najbližje približevanju takšnemu načinu dela je na nacionalni ravni predstavljal projekt »Fleksibilni predmetnik na področju osnovne šole« (Nolimal 2008), ki je fleksibilni predmetnik postavil kot enega od pogojev, da kakovostno medpredmetno povezovanje dejansko kakovostno zaživi tudi v praksi. Vendarle pa nedavna raziskava (Rupnik Vec in Slivar 2019) med drugim razkriva, da slovenski šesto- in osmošolci ocenjevanje in veliko število predmetov na dan identificirajo kot najmočnejša izvora svojega stresa. Veliko število predmetov na dan z najvišjima ocena stresnosti ocenjuje skoraj polovica $(48,5 \%)$ vprašanih, $38,4 \%$ učencev in učenk pa ta dejavnik zmerno obremenjuje. Prav $s$ tega vidika se dodatno izkazuje potreba po medpredmetnem povezovanju, ki se uresničuje na ravni posamezne šole ali posameznega oddelka, glede na potrebe in zmožnosti, ki se jih zazna na določeni šoli. To je smiselno realizirati skozi načrtno, sistematično uvedbo sprememb, ki so 
tudi ustrezno spremljane in vrednotene, pri čemer je zlasti pomembno, da pobuda za spremembe nastane znotraj, denimo znotraj oddelčnega učiteljskega zbora ali učiteljskega zbora celotne šole, in ni podana s strani zunanjih deležnikov. Takšnemu načinu načrtovanja in izvajanja ukrepov za izboljševanje vzgojno-izobraževane prakse gotovo ustreza akcijsko raziskovanje.

$Z$ vidika opredelitve različnih vrst akcijskega raziskovanja bi bilo za začetek verjetno primernejše akcijsko raziskovanje za praktične namene, ki se usmerja v reševanje vsakdanjih praktičnih problemov, ki nastajajo ob izvajanju kurikula. Na osnovi usmeritve (Cohen, Manion in Morrison 2007), da naj bi se akcijsko raziskovanje začelo $z$ uvajanjem malih sprememb in se naj bi se šele nato pristopilo $k$ večjim posegom oz. spremembam, ki lahko vodijo $v$ spreminjanje vzgojno-izobraževalne prakse $v$ širšem pomenu, $v$ spreminjanje šole ali celo sistema, je akcijsko raziskovanje za medpredmetno povezovanje smiselno začeti $v$ manjših skupinah, denimo $v$ šolskih razvojnih timih, ter nato postopoma širiti krog sodelujočih. Te manjše spremembe naj se uvajajo v krajših ciklih načrtovanja, izvajanja, spremljanja in reflektiranja, kar lahko pripomore k oblikovanju jasnih idej, predpostavk in ciljev.

$\mathrm{Na}$ tem mestu velja torej izpostaviti pomen šolskih razvojnih timov, ki naj bi se oblikovali z namenom spreminjanja vzgojno-izobraževalne prakse. Posebno pozornost (Holly 1984) je potrebno nameniti odprti, večsmerni, intenzivni komunikaciji med člani tima. Tim bo lahko deloval učinkovito le, če se bodo med člani vzpostavili odnosi zaupanja in spoštovanja, ki bodo temelj varnega socialnega učnega okolja, ki bo omogočalo odkrivanje, učenje z napakami, skupno grajenje znanja itd. Akcijsko raziskovanje temelji na dialogu, pogajanju, kritičnem prijateljstvu, sprotnem raziskovanju v samokritični skupnosti, ki v procesu interpretacije postopoma oblikuje znanje in vodi v razvoj učeče se organizacije ter kot tako lahko omogoča optimalen način delovanja in sodelovanja šolskega tima.

Pomembno je tudi, da je uvajanje novosti ali sprememb dobro načrtovano, da pri tem deluje celoten (razvojni) tim. Delo naj bo načrtovano na osnovi poznanih dejstev, prebrane literature ter izkušenj. Prav tako je potrebno novost ali spremembo natančno, sistematično spremljati - zbirati podatke; le tako bo namreč možno opraviti ustrezno evalvacijo, ki se bo uporabljala tudi za refleksijo in morebitne nadaljnje akcijske korake. $V$ celotnem procesu morajo biti jasno načrtovane aktivnosti, ki so tudi časovno opredeljene, in odgovornosti vseh članov tima, ki pa naj deluje povezovalno in suportivno.

Sklenimo: $v$ kolikor se odločimo vpeljevati medpredmetno povezovanje in poučevanje, bo akcijsko raziskovanje, ki bo načrtovano in speljano v skladu z vsemi zakonitostmi ter izhajajoč iz konkretnih potreb vzgojno-izobraževalne 
prakse, vsekakor eden izmed ustreznih pristopov pri razvijanju te pomembne usmeritve razvoja izobraževanja, ki nenazadnje lahko vodi tudi k učinkovitejši izrabi časa in učinkovitejšemu poučevanju ter učenju.

\section{Literatura}

Altrichter, H., in P. Posch. 1990. Lehrer erforscheb ihren Unterricht: Eine Einfuhrung in die Methoden Aktionsforschung. Bad Heilbrunn: Julius Klinkhardt.

Bassey, M. 1998. »Action Research for Improving Educational Practise.« V Teacher Reserach and School Improvement: Opening Doors from the Inside, ur. R. Halsall, 93-108. Buckingham: Open Unviversity Press.

Borg, W. 1965. Appying Educational Reserach: A Practical Guide for Teachers. New York: Longman.

Carr, W., in S. Kemmis. 1986. Becoming Critical: Knowing through Action Research. Geelong: Deakin University.

Creswell, J. W. 2012. Educational Research: Planning, Conductiong and Evaluation Qualitative and Quantitative Research. Boston, MA: Pearson.

Cohen, L., L. Manion in K. Morrison. 2007. Research Methods in Education. London: Routledge.

Corey, S. M. 1953. Action Research to Improve School Practices. New York: Teachers College Press.

Elliot, J. 1981. Action Research for Educational Change. Philadelphia, PA: Open University Press.

Holly, P. 1984. »Action Research: A Cautionary Note.« Classroom Action Research Network Bulletin, no. 6.

Kemmis, S., in R. McTaggart. 1988. The Aciton Research Planner. Geelong: Deakin Universtiy Press.

Kemmis, S., R. McTaggart, B. Marentič Požarnik in M. Skalar. 1991. Kako se lotimo akcijskega raziskovanja $v$ šoli. Radovljica: Didakta.

Krek, J., in M. Metljak, ur. 2011. Bela knjiga o vzgoji in izobraževanju v Sloveniji. Ljubljana: Ministrstvo za šolstvo in šport.

Lewin, K. 1948. Resolving Social Conflicts. New York: Harper.

Marentič Požarnik, B. 1987. Akcijsko raziskovanje kot model dopolnilnega izobraževanja učiteljev. Ljubljana: DZS.

Mažgon, J. 2008. Razvoj akcijskega raziskovanja na temeljnih postavkah kvalitativne metodologije. Ljubljana: Filozofska fakulteta.

Mills, G. E. 2011. Aciton Research: A Guide for the Teacher Reseracher. Upper Saddle River, NJ: Pearson.

Nolimal, F. 2008. Fleksibilni predmetnik-pot do večje avtonomije, strokovne odgovornosti in kakovosti vzgojno-izobraževalnega dela. Ljubljana: Zavod Republike Slovenije za šolstvo.

Polak, A. 2007. Timsko delo: psihološke razsežnosti timskega dela v vzgoji in izobraževanju. Ljubljana: Modrijan. 
Rupnik Vec, T., in B. Slivar. 2019. Raziskava o obremenjenosti učenk in učencev. Ljubljana: Zavod za šolstvo.

Rutar Ilc, Z. 2010. »Medpredmetne in kurikularne povezave v kontekstu učnociljnega in procesnega načrtovanja in izvajanja pouka. $\mathrm{V}$ Medpredmetne in kurikularne povezave: priročnik za učitelje, ur. Z. Rutar Ilc in K. Pavlinič Škerjanc, 71-113. Ljubljana: Zavod za šolstvo.

Sagadin, J. 1989. »Metodologija akcijskih pedagoških raziskav.« Sodobna pedagogika 40 (9-10): 383-391.

Sardoč, M., B. Domanjko, A. Gril in A. Savarin. 2004. »Medpredmetno povezovanje vzgojno-izobraževalnega procesa v 9-letni osnovni šoli: zaključno poročilo.«Pedagoški inštitut, Ljubljana.

Schon, D. A. 1983. The Reflective Practitioner: How Professionals Think in Action. New York: Basic Books.

Stringer, E. 2008. Action Research in Education. Upper Addle River, NJ: Pearson.

Velikonja, M. 2000. »Akcijsko raziskovanje kot pot h kakovosti.« Andragoška spoznanja 6 (4): 105-110.

Vogrinc, J., M. Valenčič Zuljan in J. Krek. 2007. »Akcijsko raziskovanje kot del procesov zagotavljanja kakovosti dela v vzgojno-izobraževalni instituciji.« Sodobna pedagogika 58 (5): 48-67.

Volk, M. 2019. Medpredmetne povezave z matematiko na razredni stopnji. Koper: Založba Univerze na Primorskem.

\section{The Role of Action Research in Cross-Curricular Instruction}

The paper is based on the thesis that cross-curricular integration instruction is one of the central orientations of educational development and it needs to be systematically planned and implemented. The introduction of such a method also requires careful observation and identification of the effects, i.e., the evaluation and reflection of the work done. The changes should be introduced on a small-scale and cyclically through the active participation of teachers, i.e. teamwork, which is also envisaged throughout the cross-curricular process. All these elements can be realized through action research; the main features, levels and types of these are presented in the paper. The paper concludes with an attempt to demonstrate the introduction of cross - curricular instruction wit action research, in particular through the prism of introducing the cross - curricular instruction that arise from the needs of educational practice, i.e., the needs of students and teachers and not from the dictates of external stakeholders.

Keywords: cross-curricular instruction, action research, cooperation, reflection, developmental team 